\title{
CONCEPTUALISING MANAGEMENT CONTROL SYSTEMS: ILLUSTRATIVE EVIDENCE FROM LITERATURE ON THE AUSTRALIAN BUSINESS SECTOR
} A MENEDZSMENTKONTROLL-RENDSZEREK MEGKÖZELÍTÉSEI:
PÉLDÁK AZ AUSZTRÁL ÜZLETI SZEKTOR IRODALMÁBÓL

This study is an attempt to conceptualise management control systems. Management control systems can be viewed as a broader concept which includes different components and used for varying purposes. In an organisation, control is applied at different levels and is directly related with employees of the organisation concerned. To comprehend the basics of management control systems the present study will explore the typography of the control mechanisms. Management control systems can be viewed as technical activity which is implemented in different ways in different countries. In the Australian business sector these control tools have been widely used. This study will review the experiences of implementing management control systems in the Australian business sector. Though the present study is based on Australian business sector it has policy implications to other countries and is expected to indicate potential usefulness to management control practices.

Keywords: management control systems, business sector, Australia

Ez a tanulmány kísérletet tesz a menedzsmentkontroll-rendszerek konceptualizálására. A menedzsmentkontrollrendszerekre tágabb koncepcióként tekint, amely különböző összetevőket tartalmaz és különböző célokra használható. Egy szervezetben az ellenőrzést különböző szinteken alkalmazzák, és közvetlenül kapcsolódik az érintett szervezet alkalmazottaihoz. A menedzsmentkontroll-rendszerek alapjainak megértése érdekében jelen tanulmány a vezérlési mechanizmusok tipográfiáját vizsgálja. A menedzsmentkontroll-rendszerek technikai tevékenységnek tekinthetők, amelyeket különböző országokban különböző módon alkalmaznak. Az ausztrál üzleti szektorban ezeket az ellenőrzési eszközöket széles körben alkalmazzák. Ez a tanulmány áttekinti a menedzsmentkontroll-rendszerek bevezetésének tapasztalatait az ausztrál üzleti szektorban. Habár jelen tanulmány az ausztrál üzleti szektoron alapul, ennek vonatkozásai más országokra is érvényesek, és várhatóan jelzi a menedzsmentkontroll-gyakorlatok lehetséges hasznosságát.

Kulcsszavak: menedzsmentkontroll-rendszerek, üzleti szektor, Ausztrália

\section{Funding/Finanszírozás:}

The authors did not receive any grant or institutional support in relation with the preparation of the study.

\section{Authors/Szerzők:}

Anup Chowdhury, professor, East West University, (anup@ewubd.edu)

Nikhil Chandra Shil, associate professor, East West University, (nikhil@ewubd.edu)

This article was received: 05.02. 2020, revised: 26. 09. 2020, accepted: 05. 10. 2020.

A cikk beérkezett: 2020. 02. 05-én, javítva: 2020. 09. 26-án, elfogadva: 2020. 10. 05-én. 
$\mathrm{M}$ anagement control systems have been widely used in the business sector. It is a vast area and a substantial literature on the area exists. Hofstede (1981) argued that there are no universally accepted definitions of the words "management" and "control", but he mentioned that the word "management control" is a pragmatic concern for results obtained through people. Emmanuel and Otley (1989) argued that control is concerned with a process and by this process a system adapts itself to its environment.

Management control systems can be viewed as broader concept which includes different components and used for varying purposes. Berry et al. (2009) reviewed the recent literature of emerging themes in management control based on published researches. They (2009) classified the themes into several groups: decisionmaking for strategic control, performance management for strategic control, control models for performance measurement and management, management control and new forms of organisation, control and risk, culture and information technology. Though a significant body of literature exists on management control research, Berry et al. (2009) claimed that management control research has been conducted from a narrow focus, usually on formal financial controls, with the omission of social control, clan control, culture and context. Otley et al. (1995) also expressed the opinion that management control has primarily been developed in an accounting-based framework which has been unnecessarily restrictive. Abernethy and Brownell (1997) argued that accounting information is limited to the exercise of control based simply on outputs and ignores its potential role as a form of behaviour control. On the other hand, Picard and Reis (2002) argued that most accounting research addresses management control issues, which focuses on controlling people rather than strategy formulation or tasks. Parker (1986) pointed out that accounting control have followed and lagged developments in the management literature and criticised accounting models of control for offering only imperfect reflections of management models of control. Therefore, organisations will need to design their control systems around a variety of non-accounting controls (Rockness \& Shields, 1988; Foster \& Gupta, 1994; Abernethy \& Stoelwinder, 1995). Abernethy and Brownell (1997) argued that non-accounting controls, specially personnel forms of control, contribute to organisational effectiveness, particularly where task characteristics are not well suited to the use of accounting-based controls.

Therefore, management control systems are directly related with employees of the organisation concerned. Lewis et al. (2019) identified the tension between management control and employee empowerment. Lewis et al. (2019) explored that neither structural nor psychological empowerment is the only factor for behavioural response to management control. Lewis et al. (2019) concluded that socio-ideological control and systems of accountability is also important element for empowerment.

From the above discussion it seems that the key focus of management control research rests on financial control and little attention has been paid on the social or cultural components of control. However, management control continues to be a fertile field of research development (Berry et al., 2009) and develops regularly embracing new concepts in it. However, management control systems can be viewed as technical activity which is performed in innovative and customised ways in different countries under the common tenets. Due to the authors' practical exposure with Australian business sector and motivated from the wide applicability of management control systems in Australian business sector, this study deploys an earnest effort to review the experiences of implementing management control systems in the Australian business sector. It is expected that the review makes significant contribution to practitioners and professionals of business sector from other regions in their management control thinking.

\section{LITERATURE REVIEW}

Studies on management control systems are abundant in literature but not saturated. This section presents few relevant literatures related to the context that will help the readers, particularly those who are new to this research area, to develop a conceptual understanding on management control systems and its application to wider business sector.

\section{Control}

The term 'control' is synthesised from various perspectives by different researchers based on their interactions with societal context. Emmanuel and Otley (1989) mentioned that a process is said to be controlled when it fulfils four basic conditions: Firstly, there must be the objectives of the process. Secondly, the output of the process must be measurable in accordance with the dimensions defined by the objectives. Thirdly, a predictive model of the process is required and finally, there must be a capability of taking action. They claimed that the absence of any of these preconditions the process can no longer be said in control.

Keeping away from mentioning some conditions, Anthony (1988) investigated it as a mechanism of implementing strategies. Anthony (1988) argued that control process consists of four steps. First, a standard of desired performance is specified. Second, there is a means of sensing, what is happening in the organisation and communicating to a control unit. Third, control unit compares this information with the standard. Fourth, if there is any deviation with the standard, control unit directs to take corrective action, and this is conveyed as information back to the entity which he termed as 'feedback'.

Tricker and Boland (1982) also considered control as a feedback process and mentioned that outputs are monitored and compared with standards to determine whether objectives are being attained or not. If outputs are within standards the system is considered to be in control. If not, the manager must take action. They (1982) also pointed out the necessary actions which may be the change inputs, a change in organisational process or a revision of the 
model. Merchant and Van der Stede (2007), on the other hand, argued that in the broadest sense, control systems can be viewed as having two basic functions: strategic control and management control. They viewed that strategic control has an external focus, and the managers think how an organisation, with its strengths, weakness, opportunities, and limitations can compete with the other firms in the same industry. On the other side the focus of management control issues is primarily internal, and the managers think about how they can influence employees' behaviour in desired ways. The next section discusses relevant literature on management control. made by Merchant and Van der Stede (2007). One is strategic and the other is operational. Strategic issues are related to the general stance of the organisation towards its environment and by the term operational issues they meant the effective implementation of plans designed to achieve overall goals. They (1989) further mentioned that management control can be seen as the mediating activity between strategic planning and operational control. Emmanuel and Otley (1989) argued that management control is integrative because it involves the whole organisation. The various dimensions of management control as advocated by Emmanuel and Otley (1989) is

Table 1

Dimensions of management control

\begin{tabular}{|l|l|l|l|}
\hline Features & Strategic planning & Management control & Operational control \\
\hline Focus & One aspect at a time & Whole organisation & Single task \\
\hline Persons involved & Top management, staff specialists & Top management, line managers & First-line supervisors \\
\hline \multirow{2}{*}{ Nature of information } & Tailor-made & Integrated & Tailor- made \\
\cline { 2 - 4 } & External & Mainly internal & Internal \\
\cline { 2 - 4 } & Predictive & More historical & Real-time \\
\hline Types of cost & Committed & Managed & Engineered \\
\hline Time horizon & Years & Months & Days \\
\hline Source academic discipline & Economics & Social psychology & Physical science and technology \\
\hline
\end{tabular}

Source: Emmanuel \& Otley, (1985, p. 75).

\section{Management Control}

The control literature covers a wider area which is narrowed down in management control literature to give it a targeted focus on improving performance of businesses in some selective accounting and non-accounting areas. Tricker and Boland (1982) argued that management control in any organisation depends on a set of factors. These are: the organisation structure and management style, the internal situation of the enterprise and the environmental situation of the enterprise which incorporates sociological, political and economic factors.

To give it a specific focus, Macintosh (1994) called the management control systems as management accounting and control systems. Macintosh (1994) argued that management accounting systems are only and very important part of the entire spectrum of control mechanisms which is used to motivate, monitor, measure, and sanction the actions of the managers and the employees in the organisations. Anthony et al. (1972) mentioned that the purpose of the management control systems is goal congruence that it encourages mangers to take actions that are the best interests of the company. Anthony et al. (1972) further argued that it is a total system which embraces all aspects of the company's operation.

Emmanuel and Otley (1989) made it wider and viewed that management control is a process by which managers attempt to ensure that their organisation adapts successful actions to its changing environment. Emmanuel and Otley (1989) pointed out that management control is concerned with two issues which is very much similar to the proposal summarised in Table 1 below to provide a comprehensive outlook on management control. They (1989) added that unlike strategic and operational control, management control is essentially routine affair, reporting on the performance of all aspects of an organisation's activity on a regular basis, so the areas are systematically reviewed.

\section{Management Control Systems}

The term 'management control systems' was first outlined in the seminal work of Robert Anthony (1965) where he defined it as 'the process by which managers assure that resources are obtained and used effectively and efficiently in the accomplishment of the organisation's objectives' (p. 17, quote from Ferreira \& Otley, 2009, p. 264). In line with Anthony (1965), Lorange and Morton (1974) mentioned that the fundamental purpose of management control systems is to assist management to accomplish the goals of the organisations. According to Maciariello (1984) management control systems is concerned with the coordination, information processing, and resource allocation dimensions of the management process. Maciariello (1984) argued that the purpose of management control system is to assist management in the allocation of its human, physical and technological resources to attain the goals and the objectives of an organisation. Lorange and Morton (1974) provided a framework for management control systems which identifies the pertinent control variables, the good shortterm plans, the short-term plan tracking process and diagnosis the deviations. 
Anthony and Govindarajan (2004) also viewed management control systems as a process and mentioned that by this process managers influence other members of the organisation to implement the organisation's strategies. Anthony and Govindarajan (2004) mentioned that there are two views: one is management control systems must fit the firm's strategy. According to this view strategy is first developed through a formal and rational process, and then strategy dictates the design of the firm's management process. The alternative perspective states that strategies emerge through experimentation, which is influenced by the firm's management systems. So, this view explains management control systems can impact the development of strategies. Anthony and Govindarajan (2004) claimed that when firms operate in industry contexts where environmental changes are predictable, they can develop strategy first and then design management control systems to execute the strategy but in a rapidly changing environment, it is difficult for the firms to develop strategy first and then design management systems to execute the chosen strategy. Anthony and Govindarajan (2004) mentioned that in this context strategies emerge through experimentation that is significantly influenced by the firm's management control systems. They (2004) pointed out that management control involves a variety of activities and these are planning, coordinating, communicating, evaluating, deciding and influencing. They (2004) mentioned that the elements of management control systems include strategic planning; budgeting; resource allocation; performance measurement, evaluation and reward; responsibility centre allocation; and transfer pricing. They (2004) mentioned another important dimension of management control which is task control. According to them task control assures that specified tasks are carried out efficiently and effectively. They (2004) argued that task control does not even require the presence of human beings. Machine tools, computers and robots are mechanical task control devices. They pointed out that task control systems are scientific on the other hand management control systems are behavioural. They mentioned that management control in service industries is somewhat different from management control in manufacturing companies. Anthony and Govindarajan (2004) identified some factors that have an impact on most service industries are the absence of inventory buffer, difficulty in controlling quality, labour intensive and multi-unit organisation. In a changing environment different types of control mechanisms are used in different organisation to achieve the goals of the organisation. The next section discusses these different types of management control systems.

\section{ANALYSIS AND DISCUSSION}

This section explains various typographies of management control systems and tries to integrate the application of management control systems in Australian business sector as evident in different research findings. Organisations adopt different types of control mechanisms to cope with the problems of organisational complications. It has been observed that like other countries Australian business sector has also adopted various tools of management control systems.

\section{Formal vs. Informal Management Control Systems: Maciariello and Kirby (1994)}

One of the important typographies found in management control systems is formal and informal categories of management control systems as advocated by Maciariello and Kirby (1994). They mentioned that control systems come in many shapes and forms. They (1994) divided it into two systems: formal and informal. Each of these systems is further subdivided into its subsystems and each subsystem has different elements.

In a formal system formal documentation of the structures, policies and procedures assist members of the organisation in performing their duties. Maciariello and Kirby (1994) referred to this model as supportive management systems model. They subdivided formal controlprocessesintoitsplanningandreporting dimensions. Then they considered an integration of the two interrelated processes. They (1994) mentioned that formal planning processes are strategic planning and operational planning. Strategic planning is the formal framework within which an organisation decides upon its goals and objectives, key strategies, and capital allocations. Abernethy and Guthrie (1994) studied 49 business units in Australia to examine differences in the design parameters of management information systems in firms adopting different strategic priorities. The findings indicated that the effectiveness of business units is dependent on a match between the design of the information system and the firm's strategic posture which supports the proposition of Maciariello and Kirby (1994). On the other hand, operational planning system works for the coordination of organisational activities to achieve the nearest term objectives. Abernethy and Lillis (1995) studied the impact of manufacturing flexibility on management control system design of manufacturing firms in Melbourne, Australia. The findings of the study indicated that integrative liaison devices were a critical form of control in managing the implementation of flexible manufacturing strategies which is very important in operational planning.

In the formal reporting process detailed reports are prepared to assess progress against both the strategic plans and the operational plans of the organisations. Aberenthy and Guthrie (1994) claimed that it is desirable that a fair amount of integration is needed between these two processes. The subsystems of formal control processes are management style and culture, infrastructure, rewards, coordination and integration mechanisms and control process. Management style and Cultural subsystems consists of the elements of prevailing style that is external/internal or mixed, principal values such as norms and values. The elements of infrastructure of formal control systems are the organisation structure, patterns of autonomy and measurement method such as responsibility centres, transfer pricing. Rewards in 
the formal control processes are individual rewards and group rewards, short term and long term, promotion policy. Formal coordinating mechanisms are standing committees on strategy or operations, formal conferences, and involvement techniques. Finally, the elements of formal control processes are strategic planning such as capital budgeting, operations planning such as cost accounting and budgeting, and reporting systems such as strategy/project management and operations/variance analysis. Some researchers have studied related issues in Australian business sector. Laing and Perrin (2018) surveyed 50 randomly selected printing firms in Australia. They (2018) studied the impact of management accounting methods deployed in the printing industry in Australia to allocate overhead. They (2018) observed that instead of activity-based costing main method used in this industry is absorption costing. The main reason not to use activitybased costing is that it is too complex, time consuming and costly as well. Comparing to absorption costing, activitybased costing provides less satisfaction to the users. In another case, Hoque (2014) conducted a mail-out survey on Australian manufacturing firms to identify the drivers of management control systems change. Hoque (2014) observed that a change in management accounting and control systems was significant and positively associated with greater organisational capacity to learn and in a more deeply competitive environment. Hoque (2014) further claimed that firm size and decentralisation were not extremely significant with changes in management accounting and control systems. All these studies support the presence of formal control processes in Australian business sector.

Maciariello and Kirby (1994) further argued that all organisations have informal dimensions. These dimensions are the interpersonal relationships that are not shown in the formal organisation chart. Like the formal control process, informal control process has the same sub systems. The elements of management style and cultural subsystem in the informal process are also same as formal control processes. In infrastructure subsystem, the elements are personal contacts, networks, and emergent roles. Informal rewards are usually more intrinsic in nature and these rewards contribute significantly to organisation success. The elements of informal rewards subsystems are recognition, status oriented intrinsic such as performance oriented and stature oriented and personal contact. The elements of coordination and integration subsystems are based upon trust, simple/direct/personal, telephone conversations and personal memos. Finally, the elements of informal control processes are search/alternative generation, uncertainty coping and rationalisation/ dialogue. In a study, Murthy and Guthrie (2012) observed work life balance initiatives by studying the organisational actions introduced by the managers in an Australian financial institution. They (2012) used narrative approach to analyse different internal and external documents and also collected self-accounts of employees. Findings of the study revealed that management used balance initiative to manage physical and emotional health of employees.
They (2012) observed that main focus of the management was on community volunteering which satisfied employee expectation. It showed benefit for the organisation in terms of marketing and branding. Murthy and Guthrie (2012) concluded that this initiative was helpful to motivate employees to work towards organisational goals informally.

\section{Action, Total, Ideological and Ecological Control: Czarniawska-Joerges (1988)}

Czarniawska-Joerges (1988) argued that organisational control is a form of influence, steering or regulation exerted by managerial levels vis-à-vis non-managerial levels in organisations. She (1988) mentioned four types of control systems. Her (1988) first type of control system is action control which may take the form of supervision, technical norms, calculative rules or bureaucratic regulations. She (1988) mentioned that this type of control is appropriate for contract-based employment. Her second type of control is total control which can be brought about by controlling the totality of a person, by influencing physical and/or psychological integrity. She (1988) mentioned ideological control as third type of control which is oriented at the ideologies held by organisational members. In a study, Wang and Dyball (2018) studied the impact of management control systems on fairness and performance. They surveyed 232 Australian interorganisational relationships. Their study revealed that social controls could improve procedural, distributive and interactional fairness. Czarniawska-Joerges (1988) mentioned ecological control as final type of control which is related in creation of good work conditions. Attracting new members in the organisation are the example of ecological control.

\section{Result, Action and Cultural Control: Merchant and Van der Stede (2007)}

Merchant (1982), Groot and Merchant (2000), Merchant and Van der Stede (2007) mentioned that for the control problems managers must implement one or more control mechanisms or devices that are referred to as management controls and the collection of control mechanisms are termed as a management control systems. Merchant and Van der Stede (2007) suggested three types of management control systems. These are: results control, action control and personnel / cultural control.

Merchant and Van der Stede (2007) mentioned that results control involves rewarding employees for good results or punishing them for poor results. Rewards may be monetary or non-monetary incentives. A well-known example of results control is pay for performance. They argued that results controls create meritocracies and in meritocracies rewards are given to most talented and hard-working employees rather than long tenured or socially connected employees. They (2007) observed that in many organisations this type of controls is widely used for controlling the behaviours of employees and it acts as empowering employees. The results controls are necessary for the implementation of decentralised forms 
of organisation that has largely autonomous responsibility centres. According to them results control requires four steps:
a. defining performance dimension,
b. measuring performance,
c. setting performance targets, and
d. providing rewards or punishment.

The first step comprises defining performance dimension. The predetermined goal and the measurement made are very important to shape the employees' views. If the measurement dimension is not defined correctly the organisational objectives will not be achieved and the result controls will mislead the employees to do the wrong things.

The second step is the measuring performance. It is a critical element of results control systems. It involves the assignment of numbers to objects. Merchant and Van der Stede (2007) mentioned that many objective financial measures such as net income, earning per share, and return on assets are now widely used. They (2007) also mentioned some nonfinancial measures such as market share, growth (in units), customer satisfaction, and the timely accomplishment of certain tasks. There are also some measurements those involve subjective judgments. For example, managers can be evaluated whether they are "being a team player" or "developing employees effectively'. For higher level mangers most of the measures are defined in financial terms and the measures may be either market-based performance indicators such as (stock price or returns) or accounting profits or returns (such as return on equity). Lower-level managers can be evaluated in terms of operational data.

Another important element of results control system is setting performance target. This is the standard which the employees try to achieve. Merchant and Van der Stede (2007) argued that performance target affect behaviour in two basic ways. First, as the targets are established earlier, they stimulate action and improve motivation to achieve the desired target. Second, performance targets provide the employees to interpret their own performance.

The final element of results control is providing rewards or punishments. The rewards are the motivational factors for the employees. Rewards may be monetary or non-monetary incentives. It includes salary increases, bonuses, promotions, job security, job assignments, training opportunities, freedom, recognition, and power.
On the contrary, punishments are the things which employees dislike. Punishments may be demotions, supervisor disapproval, and public embarrassment, failure to get rewards earned by peers or in extreme case loss of job. Some of the examples of rewards and punishments are provided in Table 2. Merchant and Van der Stede (2007) aptly concluded that a well-designed result control system can help to produce the desired results and it is a necessary element for employee empowerment.

Chenhall and Langfield-Smith (2003) examined the history of strategic change and the development of a performance evaluation and compensation scheme, a control tool based on gain sharing, in a manufacturing company in Sydney over a 15-year period. Data were collected through interviews. The researchers had access to a range of company documents and reports. The researchers also drew other company reports and documents including newsletters, correspondence between consultants, evaluation and assessments of head office, memos and reports, financial reports and trade union documents. The findings of the study illustrated that the researched organisation adopted team-based structures to enhance employee enthusiasm to work towards sustaining strategic change. Furthermore, the adoption of teams promoted personal trust and the sharing of values and goals. Perera et al. (1997) also studied management control systems in manufacturing firms in Sydney, Australia to investigate whether firms that maintained a customer-focused manufacturing strategy also maintained an emphasis on non-financial measures in their performance systems.

According to Merchant and Van der Stede (2007) second type of control system is actions controls which are the most direct form of management control. They pointed out that this type of control involves ensuring employees to perform or not to perform certain actions which are known to be beneficial or harmful to the organisation. This type of control are effectively useable only when managers know what actions are desirable or undesirable and the managers have the ability to make sure that the desirable actions occur or the undesirable actions do not occur. They (2007) mentioned four basic forms of action control:
a. behavioural constraints,
b. preaction reviews,
c. action accountability, and
d. redundancy.

\section{Positive and negative rewards}

\begin{tabular}{|l|l|}
\hline \multicolumn{1}{|c|}{ Types of Rewords } & \multicolumn{1}{c|}{ Titles } \\
\hline Positive & $\begin{array}{l}\text { Autonomy, Power, Opportunities to participate in important decision-making processes, Salary increases, } \\
\text { Bonuses, Stock options, Restricted stock, Praise, Recognition, Promotions, Titles, Job assignments, } \\
\text { Office assignments, Reserved parking places, Country club memberships, Job security, Vacation trips, } \\
\text { Participation in executive development programmes, Time off }\end{array}$ \\
\hline Negative & $\begin{array}{l}\text { Interference in job from superior(s), Loss of job, Zero salary increases, Assignment to unimportant tasks, } \\
\text { Chastisement (public or private), No promotion, Demotion, Public humiliation }\end{array}$ \\
\hline
\end{tabular}

Source: Merchant \& Van der Stede (2007, p. 369) 
Behavioural constraints can be considered as a negative form of action control. It prevents people from doing things that should not be done. The constraints can be applied physically or administratively. The examples of physical constraints are locks on desks, computer passwords and restricted entry to the valuable inventory area and sensitive information source. Some behavioural constraints devices are technically sophisticated and expensive, such as magnetic identification-card readers, voice-pattern detectors, and fingerprint or eyeball-pattern readers. Administrative constraints can also be used to place restrictions on an employee's abilities to perform all or a part of specific acts. It involves the restriction of decision-making authority. Separation of duties can also be treated as an administrative control. It involves dividing up the tasks necessary for the accomplishment of certain sensitive duties among the various employees.

Sundin and Brown (2017) conducted a qualitative case study on a large Australian listed property trust. They (2017) investigated agent's interests integrated with environmental objectives using management control systems. They (2017) observed both single and multiple objectives. In single objective, they identified relationships between environment and management control systems. In multiple objectives, they identified priorities among environment, economic trade-offs and management control systems.

Another important element of action control is preaction review. Merchant and Van der Stede (2007) mentioned that pre-action reviews incorporate scrutiny of the action plans of the employees being controlled. Pre-action reviews appear in different forms, some of them are formal and others informal. Formal pre-action reviews are needed during organisational planning and budgeting process. An informal talk between a superior and a subordinate on the progress of a specific project is an example of informal pre-action review.

Action accountability means employees are accountable for the actions they take. Merchant and Van der Stede (2007) mentioned that the functioning of action accountability controls requires defining what actions are acceptable or unacceptable, communicating those definitions to employees, observing or otherwise tracking what happens, and finally, rewarding good actions or punishing actions that deviate from the acceptable. Actions for which employees are to be held accountable can be communicated either administratively or socially. Administrative modes of communication comprise the use of work rules, policies and procedures, contract provisions, and company codes of conduct.

In a study, Baird and Schoch (2013) observed the outsourcing practices adopted by Australian private sector organisations. They (2013) also compared the level of outsourcing between privateand publicsectororganisations. Their research assessed the influence of management control systems on outsourcing success. Findings revealed that compared to public sector outsourcing private sector outsourcing is not successful. They (2013) concluded that outsourcing success depends on tightness of control. In a separate study, Langfield-Smith and Smith (2003) explored the design of management control systems and the role of trust in outsourcing relationships. They observed that since the early 1990s, there has been significant growth in outsourcing, in both public and private sector. It was applied not only to manufacturing activities but also to administrative and management functions. They (2003) conducted a case study, and an Australian energy company was their research site. Data were collected through semi structured interviews with the managers in the electricity firm who were involved in the decision to outsource the operation and in the ongoing management of the outsourced functions. The findings of their study revealed that the characteristics of the outsourcing transactions seemed to meet the requirements of a trust-based pattern of control rather than a market based or bureaucratic based pattern. They (2003) identified that control was achieved through the development of outcome control and social controls and through development of trust, particularly goodwill trust.

According to Merchant and Van der Stede (2007) redundancy means assigning more employees or machines to a task. In fact, it is the backup of employees or machines to perform the task satisfactorily. Redundancy is common in computer facilities, security functions, and other critical operations. However, it is infrequently used in other areas because it is expensive. Moreover, assigning more than one employee to the same task usually results in conflict, frustration, and/or boredom. Merchant and Van der Stede (2007) pointed out that action controls can also be used to identify whether they prevent or detect undesirable behaviours. Most action controls are aimed at preventing undesirable behaviours.

Merchant and Van der Stede (2007) classifies personnel and cultural control as the third form of control. According to them personnel controls build on employees' natural tendencies to control and or motivate themselves. They (2007) argued that personnel controls provide any of three fundamental purposes. First, some of them clarify expectations. They help to make sure that each employee understands organisation's expectations. Second, some of them help to make sure that each employee is capable to do a good job and they have all the qualities such as experience and intelligence and also the necessary resources are available such as information and time needed to do a good job. The third purpose of personnel control is some of them help to make sure that each employee will engage in self-monitoring. Self-monitoring is an inner force that pushes most employees to want to do a good job, and the employees are committed to achieve the organisation's goals. Petroulas et al. (2010) examined generational workplace preferences for management control systems. They (2010) undertook an exploratory study of three generations and their management control preferences in a large Australian Professional services firm. Results indicated that each generation presented different characteristics and these differences were linked to generational management control preferences specifically in goal setting, performance evaluation, 
administrative controls and incentives. Merchant and Van der Stede (2007) identified three major methods of implementing personnel controls. These are: Selection and placement, Training and Job design and provision of necessary resources.

Selection and placement involve finding the right people, giving them a good working environment and at the same time providing them the necessary resources to do a specified job. It will certainly increase the probability that the job will be done correctly. In general, firms devote substantial time and effort to employee selection and placement, and a large literature describes how these tasks should be done properly. Merchant and Van der Stede (2003) mentioned that much of this literature describes an effective selection and placement depends on employee's education, experience, past success, personality and social skills.

Training is another method of personnel controls. It can be used to ensure that employees are well informed about the assigned tasks and they are also fully aware of the results and actions that are expected from them. It will give the employees a greater sense of professionalism and in this context, it can also have positive motivational effects. Many organisations use formal training programme such as in classroom settings, to improve the skills of their personnel and also much training programme takes place informally, such as through employee mentoring.

Job design the other type of personnel control encompasses designing jobs in such a way that the employees can do their tasks with a high degree of success. To show a better performance in the job, employees need a particular set of resources. These resources are highly job specific, which includes such items as information, equipment, supplies, staff support, decision aids or freedom from interruption.

Cultural controls of an organisation consist of a set of shared meanings, values, social norms and beliefs that are rooted in that organisation and which influence the actions of the members of that organisation. Merchant and Van der Stede (2007) mentioned that cultural controls can be used effectively where members of a group have emotional ties to one another. The cultural norms are organised in written and unwritten rules that shape employees' behaviours. Strong organisational cultures cause employees to work together in an energetic and well-coordinated fashion. Merchant and Van der Stede (2007) suggested five important methods of shaping culture, and thus effecting cultural controls, are: codes of conduct, group-based rewards, intra organisational transfers, physical and social arrangements and tone at the top.

Merchant and Van der Stede (2007) mentioned that codes of conduct are formal, written documents which provide general statements of corporate values and commitments to stakeholders and ways in which top management would like the organisation to function. Each of these codes or statements guides the employees to understand what behaviours are expected in the absence of clearly defined rules or principles. These statements may include about the quality and customer satisfaction, fair treatment of staff and suppliers, employee safety, innovation, risk taking, adherence to strict ethical principles, open communications, a minimum of bureaucracy, and willingness to change.

Group based reward is considered as an important form of cultural control. It is based on collective achievement and includes bonus, profit-sharing, or gain sharing plans. These rewards may be given on overall corporate or divisional performance, in terms of growth, or on the basis of profits or accounting returns. Intra organisational transfer is another choice to transmit culture. Merchant and Van der Stede (2007) argued that employees are transferred throughout the organisation to give them a better understanding about the organisation and at the same time to improve the socialisation of the employees. They further argued that employee rotation is also sometimes effective in reducing the occurrence of fraud because it prevents employees from becoming too familiar with certain entities, activities, colleagues, and/ or transactions.

Physical and social arrangements can also shape organisational culture. Physical arrangements include office plans, architecture, and interior decor. Social arrangements may be dress codes and vocabulary. Merchant and Van der Stede (2007) mentioned that corporate managers can shape culture by setting the proper tone at the top. In a corporate culture, managers are regarded as role models. They cannot say one thing and do another. Their statement should be consistent with the type of culture they are trying to create and at the same time their behaviours should be consistent with their statements.

\section{Beliefs, Boundary, Diagnostic and Interactive Control Systems: Simons (1995)}

Simons (1995) defined management control systems as the formal, information-based routines and procedures managers use to maintain or alter patterns in organisational activities. Taylor et al. (2019) conducted a case study on an Australian technology start-up company over a twelve-month period. They (2019) showed to achieve innovation, management control systems can promote in generating ideas and 'buy-in' across all functional areas. However, Simons (1995) identified four basic levers of management control: beliefs, boundary, diagnostic and interactive control systems. A beliefs system is a formally communicated and systematically reinforced set of explicit organisational definitions. It includes basic values, purpose and direction of the organisation. A formal belief system is created and communicated through credos, mission statements, and statement of purpose. Simon's beliefs system is comparable with Merchant and Van der Stede's (2007) personnel control. Boundary systems delineate the acceptable domain of activity and establish limits, based on defined business risks, to opportunity seeking. Boundary systems correspond to Merchant and Van der Stede's (2007) action controls. Simon's third lever of control systems is diagnostic control systems. Simon 
defined it as the backbone of traditional management control, and it is designed to ensure predictable goal achievement. It is formal information systems managers use to monitor organisational outcomes and correct deviations from present standards. These systems are similar to Marchent and Van der Stede's (2007) results control. Simon's last lever of control is interactive control systems which stimulate search and learning, allowing new strategies to emerge as participants throughout the organisation respond to perceived opportunities and threats and many systems can be used interactively. In a study, Alam and Nandan (2010) explored the nature of context specific issues and challenges facing small accounting practices in Australian regional and rural centres. They (2010) used a qualitative case study. Data were collected through semi-structured interviews with the managers and owners and from relevant archival documents. They (2010) observed that these firms faced a continuously changing environment which required innovative strategies and structures. Furthermore, they argued that there were significant differences between small accounting practices and specifically how they addressed their contextual uncertainties.

$\mathrm{Su}$ et al. (2017) surveyed 343 general managers of Australian manufacturing organisations. They (2017) tried to explore relationships of Simon's (1995) integrative and diagnostic management control systems on organisational life cycle. Their study revealed that both control mechanisms are significant at birth and growth stage than maturity and revival stage. In another study, $\mathrm{Su}$ et al. (2013) surveyed 1,000 General Managers in
Moores and Yuen (2001) conducted a study adopting a configurationally approach that captured the variables of strategy, structure, leadership and decision-making style and the relationships of these with management accounting systems from an organisational life-cycle perspective. The clothing and footwear industry in Australia were selected as the research sample. Data were collected by mail survey and field studies, with questionnaires sent to the chief executive officers of businesses targeting over 600 establishments. The researchers conducted interviews and collected documentary evidences in their field work. The findings of the study revealed that formality in management accounting systems changed to complement organisational characteristics across life-cycle stages. Baines and Langfield-Smith (2003) examined the relationship between the changing competitive environment and a range of organisational variables to management accounting change. The study was based on a postal survey. Questionnaire was sent to the general managers of 700 manufacturing organisations in Australia. The firms selected were independent business units in large firms or companies. The findings of the study indicated that in an increasingly competitive environment increased focus on differentiation strategies are needed. The study identified that these strategies influenced changes in organisational design, advanced manufacturing technology and advanced management accounting changes. Based on the analysis of different typographies of management control system, a synthesis of management control systems is presented in Figure 1. with reference to three representative works which is adapted from (Straub \& Zecher, 2013).

\section{Comparison of the MCS concept}

Figure 1.

\begin{tabular}{c|c|c|}
\cline { 2 - 2 } $\begin{array}{c}\text { Informal } \\
\text { controls, } \\
\text { explicitly } \\
\text { integrated }\end{array}$ & $\begin{array}{c}\text { Merchant \& Van der Stede's } \\
(2007)\end{array}$ & $\begin{array}{c}\text { Simons (1995) } \\
\text { Belief systems, interactive control } \\
\text { Action controls, result controls, } \\
\text { personnel/cultural controls }\end{array}$ \\
\cline { 2 - 3 } $\begin{array}{c}\text { Informal } \\
\text { controls, not } \\
\text { explicitly } \\
\text { integrated }\end{array}$ & $\begin{array}{c}\text { Anthony \& Govindarajan (2004) } \\
\text { control systems, diagnostic }\end{array}$ \\
\cline { 2 - 3 } & $\begin{array}{c}\text { Strategic planning, budgeting, } \\
\text { responsibility centre, report, actual versus } \\
\text { plan etc. }\end{array}$ \\
\cline { 2 - 3 } & Command and Control & \\
\hline
\end{tabular}

Source: adapted from Straub \& Zecher (2013, p. 252)

Australian manufacturing business units. Their objective was to observe the relationships between management control systems and organisational life cycle. Their study revealed that three types of control mechanisms input, behaviour and output have impact on life cycle. Su et al. (2013) showed that at birth and growth stage of an organisation, behaviour and input controls are very significant. However, birth, growth, maturity and revival stages both type of controls are significant.

\section{CONCLUSION}

The objective of the present study is to understand the basics of management control systems and review the research literature related to management control systems on Australian business sector. The research literature reveals that a variety of 'styles of use' are associated with the control systems. The study noted that in Australia numerous studies have explored issues 
on management control in the business sector (see Appendix 1 for a summary). The illustrative literature identified that numerous studies have been undertaken to explore management control systems in different contexts. From the literature it has been identified that the key focus of management control research in Australia is on financial control and little attention is paid on people, culture, strategy and action or tasks. At the same time, it was also observed that many of them were conducted using quantitative research approaches such as surveys which allows findings to be generalised, but do not allow for an in depth understanding of how and why these control technologies exist. There is still a dearth of closely observed studies such as the case study approach describing the experiences of organisations using these control technologies. As Australia is pioneer in driving business growth through implementing various management control systems, this conceptual study can help the beginners to contextualise the issue and supports them in devising tailored management control systems for their particular organisations.

\section{References}

Abernethy, M. A., \& Guthrie, C. H. (1994). An empirical assessment of the "fit" between strategy and management information system design. Accounting and Finance, 34(2), 49-66.

https://doi.org/10.1111/j.1467-629X.1994.tb00269.x

Abernethy, M. A., \& Lillis, A. M. (1995). The impact of manufacturing flexibility on management control system design. Accounting, Organizations and Society, 20(4), 241-258.

https://doi.org/10.1016/0361-3682(94)E0014-L

Abernethy, M. A., \& Stoelwinder, J. U. (1995). The role of professional control in the management of complex organizations. Accounting, Organizations and Society, 20(1), 1-17.

https://doi.org/10.1016/0361-3682(94)E0017-O

Abernethy, M. A., \& Brownell, P. (1997). Management Control Systems in Research and Development Organisations: The Role of Accounting, Behavior and Personnel Controls. Accounting, Organizations and Society, 22(3/4), 233-248. https://doi.org/10.1016/S0361-3682(96)00038-4

Alam, M., \& Nandan, R. (2010). Organisational change and innovation in small accounting practices: evidence from field. Journal of Accounting and Organizational Change, 6(4), 460-476. https://doi.org/10.1108/18325911011091828

Anthony, R. N., Dearden, J., \& Vangil, R. F. (1972). Management Control Systems: Cases and Readings. Boston: Richard D. Irwin, Inc.

Anthony, R. N. (1988). The Management Control Function. Cambridge, Mass.: Harvard Business School Press.

Anthony, R. N., \& Govindarajan, V. (2004). Management Control Systems. Boston, Mass.: McGraw Hill Irwin.

Baines, A., \& Langfield-Smith, K. (2003). Antecedents to management accounting change: a structural equation approach. Accounting, Organizations and Society, 28(7-8), 675-698.

https://doi.org/10.1016/S0361-3682(02)00102-2

Baird, K., \& Schoch, H. (2013). The adoption and success of private sector outsourcing in Australia. International Journal of Accounting, Auditing and Performance Evaluation, 9(3), 199-223.

https://doi.org/10.1504/IJAAPE.2013.055894

Berry, A. J., Coad, A. F., Harris, E. P., Otley, D. T., \& Stringer, C. (2009). Emerging themes

in management control: A review of recent literature. The British Accounting Review, 41, 2-20.

https://doi.org/10.1016/j.bar.2008.09.001

Chenhall, R. H., \& Langfield-Smith, K. (2003). Performance Measurement and Reward Systems, Trust, and Strategic Change. Journal of Management Accounting Research, 15(1), 117-143.

https://doi.org/10.2308/jmar.2003.15.1.117

Czarniawska-Joerges, B. (1988). Dynamics of Organizational Control: The Case of Berol Kemi AB. Accounting, Organizations and Society, 13(4), 415-430. https://doi.org/10.1016/0361-3682(88)90014-1

Emmanuel, C. R., \& Otley, D. T. (1985). Accounting for Management Control. New York: Van Nostrand Reinhold.

Ferreira, A., \& Otley, D. (2009). The design and use of performance management systems: An extended framework for analysis. Management Accounting Research, 20(4), 263-282.

https://doi.org/10.1016/j.mar.2009.07.003

Foster, G., \& Gupta, M. (1994). Marketing, cost management and management accounting. Journal of Management Accounting Research, 6, 43- 77.

Groot, T., \& Merchant, K. A. (2000). Control of international joint ventures. Accounting, Organizations and Society, 25(6), 579-607. https://doi.org/10.1016/S0361-3682(99)00057-4

Hofstede, G. (1981). Management Control of Public and Not - For - Profit Activities. Accounting, Organizations and Society, 6(3), 193-211. https://doi.org/10.1016/0361-3682(81)90026-X

Hoque, Z. (2014). Drivers of Management Control Systems Change: Additional Evidence from Australia. Advances in Management Accounting, 23, 65-92. https://doi.org/10.1108/S1474-787120140000023002

Laing. G. K., \& Perrin, R. W. (2018). Management Accounting in the Australian Printing

Industry: A Survey. Journal of New Business Ideas and Trends, 16(3), 13-19.

Langfield Smith, K., \& Smith, D. (2003). Management control systems and trust in outsourcing Relationships. Management Accounting Research, 14(3), 281-307. https://doi.org/10.1016/S1044-5005(03)00046-5

Lewis, R. L., Brown, D. A., \& Sutton, N. C. (2019). Control and empowerment as an organising paradox: implications for management control systems. Accounting, Auditing \& Accountability Journal, 32(2), 483-507. https://doi.org/10.1108/AAAJ-11-2017-3223 
Lorange, P., \& Scott Morton, M. S. (1974). A framework for management control systems. Sloan Management Review, 16(1), 41-56.

Maciariello. J. A. (1984). Management Control Systems. Upper-Saddle River: Prentice-Hall.

Maciariello. J. A., \& Kirby, C. J. (1984). Management Control Systems: Using Adaptive Systems to Attain Control. Upper-Saddle River: Prentice-Hall.

Macintosh, N. B. (1994). Management Accounting and Control Systems: An Organisational and Behavioral Approach. New York: John Wiley \& Sons Ltd.

Merchant, K. A. (1982). The Control Function of Management. Sloan Management Review, Summer, 43- 55.

Merchant, K. A., \& Van der Stede, W. A. (2007). Management Control Systems. Harlow: Pearson Education Limited.

Moores, K., \& Yuen, S. (2001). Management accounting systems and organisational configuration: a life-cycle perspective. Accounting Organizations and Society, 26(4-5), 351-389.

https://doi.org/10.1016/S0361-3682(00)00040-4

Murthy, V., \& Guthrie, J. (2012). Management control of work-life balance. A narrative study of an Australian financial institution. Journal of Human Resource Costing \& Accounting, 16(4), 258-280. https://doi.org/10.1108/14013381211317248

Otley, D., Broadbent, J., \& Berry, A. (1995). Research in Management Control: An Overview of its Development. British Journal of Management, 6, S31-S34. https://doi.org/10.1111/j.1467-8551.1995.tb00136.x

Parker, L. D. (1986). Developing Control Concepts in the 20th Century. New York: Garland.

Perera, S., Harrison, G., \& Poole, M. (1997). Customerfocused manufacturing strategy and the use of operations-based non-financial performance measures: A research note. Accounting, Organizations and Society, 22(6), 557-572. https://doi.org/10.1016/S0361-3682(96)00048-7

Petroulas, E., Brown, D. A., \& Sundin, H. (2010). Generational Characteristics and Their Impact on Preference for Management Control Systems. Australian Accounting Review, 20(3), 221-240. https://doi.org/10.1111/j.1835-2561.2010.00099.x

Picard, R. R., \& Reis, P. (2002). Management control systems design: a metaphorical integration of national culture implications. Managerial Auditing Journal, 17(5), 222- 233.

https://doi.org/10.1108/02686900210429632

Rockness, H. O., \& Shields, M. D. (1988). An empirical analysis of the expenditure budget in research and development. Contemporary Accounting Research, $4(2), 568-581$.

https://doi.org/10.1111/j.1911-3846.1988.tb00685.x

Simons, R. (1995). Levers of Control: How Managers Use Innovative Control Systems to Drive Strategic Renewal. Boston, Mass.: Harvard Business School Press.

Straub, E., \& Zecher, C. (2013). Management control systems: a review. Journal of Management Control, 23(4), 233-268.

https://doi.org/10.1007/s00187-012-0158-7

Su, S., Baird, K., \& Schoch, H. (2017). Management control systems: The role of interactive and diagnostic approaches to using controls from an organizational life cycle perspective. Journal of Accounting \& Organizational Change, 13(1), 2-24. https://doi.org/10.1108/JAOC-03-2015-0032

Su, S., Baird, K., \& Schoch, H. (2013). Management control systems from an organisational life cycle perspective: The role of input behavior and output controls. Journal of management \& Organization, 19(5), 635-658.

https://doi.org/10.1017/jmo.2014.7

Sundin, H., \& Brown, D. A. (2017). Greening the black box: integrating the environment and management control systems. Accounting, Auditing \& Accountability Journal, 30(3), 620-642. https://doi.org/10.1108/AAAJ-03-2014-1649

Taylor, D., King, R., \& Smith, D. (2019). Management controls, heterarchy and innovation: a case study of a start-up company. Accounting, Auditing \& Accountability Journal, 32(6), 1636-1661. https://doi.org/10.1108/AAAJ-11-2017-3208

Tricker, R. I., \& Boland, R. J. (1982). Management Information and Control Systems. New York: Wiley.

Wang, A., \& Dyball, M. C. (2018). Management controls and their links with fairness and performance in interorganisational relationships. Accounting and Finance, 59(3), 1835-1868.

https://doi.org/10.1111/acfi.12408 
Summary of management control systems literature in the business sector- Australian perspective

Appendix 1.

\begin{tabular}{|c|c|c|}
\hline Authors (Date) & Research Topic & Findings \\
\hline Taylor et al. (2019) & $\begin{array}{l}\text { Case study on management control } \\
\text { systems of an Australian technology } \\
\text { start-up company. }\end{array}$ & $\begin{array}{l}\text { They (2019) showed to achieve innovation, management } \\
\text { control systems can promote in generating ideas and } \\
\text { 'buy-in' across all functional areas. }\end{array}$ \\
\hline Laing \& Perrin (2018) & $\begin{array}{l}\text { Impact of management accounting } \\
\text { methods deployed in the printing } \\
\text { industry in Australia }\end{array}$ & $\begin{array}{l}\text { Observed that instead of activity based costing main } \\
\text { method used in this industry is absorption costing. } \\
\text { The main reason not to use activity based costing is } \\
\text { that it is too complex, time consuming and costly as } \\
\text { well. Comparing to absorption costing, activity based } \\
\text { costing provides less satisfaction to the users. }\end{array}$ \\
\hline Wang \& Dyball (2018) & $\begin{array}{l}\text { Studied the impact of management } \\
\text { control systems on fairness and } \\
\text { performance. }\end{array}$ & $\begin{array}{l}\text { Their study revealed that social controls could improve } \\
\text { procedural, distributive and interactional fairness. }\end{array}$ \\
\hline Su et al. (2017) & $\begin{array}{l}\text { Relationships of Simon's (1995) } \\
\text { integrative and diagnostic management } \\
\text { control systems on organisational life } \\
\text { cycle. }\end{array}$ & $\begin{array}{l}\text { Their study revealed that both control mechanisms are } \\
\text { significant at birth and growth stage than maturity and } \\
\text { revival stage. }\end{array}$ \\
\hline Sundin \& Brown (2017) & $\begin{array}{l}\text { Agent's interests integrated with } \\
\text { environmental objectives through the } \\
\text { use of management control systems. }\end{array}$ & $\begin{array}{l}\text { Observed both single and multiple objectives. In } \\
\text { single objective they identified relationships between } \\
\text { environment and management control systems. In } \\
\text { multiple objectives, they identified priorities among } \\
\text { environment, economic trade-offs and management } \\
\text { control systems. }\end{array}$ \\
\hline Hoque (2014) & $\begin{array}{l}\text { Survey on Australian manufacturing } \\
\text { firms to identify the drivers of } \\
\text { management control systems change. }\end{array}$ & $\begin{array}{l}\text { Observed that a change in management accounting and } \\
\text { control systems was significant and positively associated } \\
\text { with greater organisational capacity to learn and in a } \\
\text { more deeply competitive environment. Hoque (2014) } \\
\text { further claimed that firm size and decentralization were } \\
\text { not extremely significant with changes in management } \\
\text { accounting and control systems. }\end{array}$ \\
\hline Baird \& Schoch (2013) & $\begin{array}{l}\text { Outsourcing practices adopted by } \\
\text { Australian private sector organisations. }\end{array}$ & $\begin{array}{l}\text { Findings revealed that compared to public sector } \\
\text { outsourcing private sector outsourcing is not } \\
\text { successful. They (2013) concluded that outsourcing } \\
\text { success depends on tightness of control. }\end{array}$ \\
\hline Su et al. (2013) & $\begin{array}{l}\text { The relationships between management } \\
\text { control systems and organisational life } \\
\text { cycle. }\end{array}$ & $\begin{array}{l}\text { Study revealed that three types of control mechanisms } \\
\text { input, behaviour and output have impact on life cycle. } \\
\text { Su et al. (2013) showed that at birth and growth stage of } \\
\text { an organisation, behaviour and input controls are very } \\
\text { significant. }\end{array}$ \\
\hline Murthy \& Guthrie (2012) & $\begin{array}{l}\text { Work life balance initiatives and } \\
\text { organisational actions introduced by } \\
\text { the managers in an Australian financial } \\
\text { institution. }\end{array}$ & $\begin{array}{l}\text { Findings of the study revealed that management used } \\
\text { balance initiative to manage physical and emotional } \\
\text { health of employees. They (2012) observed that } \\
\text { main focus of the management was on community } \\
\text { volunteering which satisfied employee expectation. } \\
\text { It showed benefit for the organisation in terms of } \\
\text { marketing and branding. }\end{array}$ \\
\hline Alam \& Nandan (2010) & $\begin{array}{l}\text { The nature of context specific issues } \\
\text { and challenges facing small accounting } \\
\text { practices }\end{array}$ & $\begin{array}{l}\text { There were significant differences between small } \\
\text { accounting practices and specifically how they } \\
\text { addressed their contextual uncertainties. }\end{array}$ \\
\hline Petroulas et al. (2010) & $\begin{array}{l}\text { Generational workplace preferences for } \\
\text { management control systems. }\end{array}$ & $\begin{array}{l}\text { Results indicated that each generation presented } \\
\text { different characteristics and these differences were } \\
\text { linked to generational management control preferences } \\
\text { specifically in goal setting, performance evaluation, } \\
\text { administrative controls and incentives. }\end{array}$ \\
\hline
\end{tabular}




\begin{tabular}{|c|c|c|}
\hline $\begin{array}{l}\text { Baines \& Langfield-Smith } \\
\text { (2003) }\end{array}$ & $\begin{array}{l}\text { Relationship between the changing } \\
\text { competitive environment and a range of } \\
\text { organisational variables to management } \\
\text { accounting change }\end{array}$ & $\begin{array}{l}\text { An increasingly competitive environment has resulted } \\
\text { in an increased focus on differentiation strategies. These } \\
\text { strategies has influenced changes in organisational } \\
\text { design, advanced manufacturing technology and } \\
\text { advanced management accounting changes. }\end{array}$ \\
\hline $\begin{array}{l}\text { Langford-Smith \& Smith } \\
\text { (2003) }\end{array}$ & $\begin{array}{l}\text { Design of management control systems } \\
\text { and the role of trust in outsourcing } \\
\text { relationships. }\end{array}$ & $\begin{array}{l}\text { The characteristics of the outsourcing transactions } \\
\text { seemed to meet the requirements of a trust based pattern } \\
\text { of control rather than a market-based or bureaucratic- } \\
\text { based pattern. }\end{array}$ \\
\hline $\begin{array}{l}\text { Chenhall \& Langfield-Smith } \\
\text { (2003) }\end{array}$ & $\begin{array}{l}\text { Strategic change and the development } \\
\text { of performance evaluation and } \\
\text { compensation scheme }\end{array}$ & $\begin{array}{l}\text { Adopted team-based structures to enhance employee } \\
\text { enthusiasm to work towards sustaining strategic } \\
\text { change. }\end{array}$ \\
\hline Moores \& Yuen (2001) & $\begin{array}{l}\text { Strategy, structure, leadership and } \\
\text { decision-making style and their } \\
\text { relationships with management } \\
\begin{array}{lll}\text { accounting systems from an } \\
\text { organisational life-cycle perspective }\end{array}\end{array}$ & $\begin{array}{l}\text { Management accounting system formally changed to } \\
\text { complement organisational characteristics across life- } \\
\text { cycle stages. }\end{array}$ \\
\hline Perera et al. (1997) & $\begin{array}{l}\text { Customer-focused manufacturing } \\
\text { strategy and the use of operations based } \\
\text { non-financial performance measures }\end{array}$ & $\begin{array}{l}\text { Support is found for the hypothesized association } \\
\text { between customer-focused strategy and the use of non- } \\
\text { financial performance measures but not for the link to } \\
\text { organisational performance. }\end{array}$ \\
\hline Abernethy \& Lillis (1995) & $\begin{array}{l}\text { Impact of manufacturing flexibility on } \\
\text { management control system design of } \\
\text { manufacturing firms }\end{array}$ & $\begin{array}{l}\text { Integrative liaison devices are a critical form of control } \\
\text { in managing the implementation of flexible } \\
\text { manufacturing strategies. }\end{array}$ \\
\hline Aberenethy \& Guthrie (1994) & $\begin{array}{l}\text { Strategy and management information } \\
\text { system design }\end{array}$ & $\begin{array}{l}\text { The effectiveness of business units is dependent on a } \\
\text { match between the design of the information system } \\
\text { and the firm's strategic posture. }\end{array}$ \\
\hline
\end{tabular}

